CZASOPISMO INŻYNIERII LĄDOWEJ, ŚRODOWISKA I ARCHITEKTURY JOURNAL OF CIVIL ENGINEERING, ENVIRONMENT AND ARCHITECTURE

JCEEA, t. XXXIV, z. 64 (3/II/17), lipiec-wrzesień 2017, s. 7-18, DOI:10.7862/rb.2017.149

Lukasz BAJDA ${ }^{1}$

Adam RYBKA ${ }^{2}$

\title{
PROJEKTOWANIE PARTYCYPACYJNE W ZAŁOŻENIACH URBANISTYCZNYCH OSIEDLI MIESZKANIOWYCH RZESZOWA JAKO ŹRÓDŁO WYMIANY WIEDZY I DOŚWIADCZEŃ
}

\begin{abstract}
W czasach kiedy to inwestorzy tworzą urbanistykę i architekturę, potrzebny jest dialog pomiędzy developerem a mieszkańcami miasta. Doświadczenia i opinie mieszkańców (relacje wynikające z użytkowania danej przestrzeni miejskiej) istniejących już osiedli powinny być uwzględniane i badane przy tworzeniu nowych planów rozwoju miasta. O rozwoju miasta należy rozmawiać. Jeśli chcemy rozmawiać o rozwoju całego miasta potrzebujemy nie tylko planu i makiety miasta. Należy stworzyć miejsce wymiany opinii i poglądów dla każdego zainteresowanego. (Mieszkańcy - Planiści - Projektanci - Inwestorzy). Miejsce, w którym mieszkańcy mają realny wpływ na zmiany zachodzące w ich mieście. Miejsce, w którym na żywej tkance miasta (np. makiecie) można obserwować zmiany zachodzące w mieście i mieć na nie wpływ. (Przykładem może być INFOBOX w Gdyni). Przestrzeń w której każdy, nie tylko mieszkańcy ale również inwestorzy, radni, architekci, urbaniści mogą wymieniać swoje opinie. Udział i zaangażowanie mieszkańców w tworzeniu miasta powinno być coraz większe. Warto, by świadoma polityka marketingowa władz miasta wykorzystywała potencjał z już istniejących osiedli mieszkaniowych przy tworzeniu kolejnych planów miasta. Stawiając na wymianę wiedzy i poglądów. W ,nowym”, kształtującym swe oblicze i swą specyfikację mieście trzeba na to kilku pokoleń. (do wymiany poglądów) np. istniejące po dzień dzisiejszy założenia urbanistyczne z epoki modernizmu dostarczają wielu cennych wskazówek. Nie tylko założenie urbanistyczne ale i opinia mieszkańców mogą dać nowy kierunek i pogląd do kształtowania nowych przestrzeni w mieście. Przykładami mogą być już istniejące założenia w mieście. Np osiedle Pułaskiego, którego wyrazista kompozycja oraz spełnienie zapisów planów miejscowych pokazują jak architekci poprzez szczegółową analizę tego terenu wyrazili formę i usytuowanie budynków. Zmagając się z uciążliwymi warunkami środowiska stworzyli zabudowę ciekawą w formie i funkcji. Dalsza analiza przeprowadzona
\end{abstract}

\footnotetext{
${ }^{1}$ Autor do korespondencji/corresponding author: Łukasz Bajda, Politechnika Rzeszowska, Zakład Urbanistyki i Architektury, al. Powstańców Warszawy 12, 35-959 Rzeszów; tel.: 17743 2142; e-mail: lb@prz.edu.pl

2 Adam Rybka, Politechnika Rzeszowska, Zakład Urbanistyki i Architektury, al. Powstańców Warszawy 12, 35-959 Rzeszów; tel.: 17865 1624; e-mail: akbyr@prz.edu.pl
} 
na podstawie osiedli i założeń urbanistycznych: osiedle Baranówka, osiedle przy ulicy Hetmańskiej, osiedle przy ulicy Dąbrowskiego, osiedle Zalesie.

Słowa kluczowe: interakcja, uczestnictwo jednostek, miejscowy plan

\section{Współdzielenie zasobów}

\subsection{Wprowadzenie}

Żyjemy w świecie globalnej urbanizacji, ludzie coraz częściej wybierają miasta jako miejsce swojego życia. Tempo rozwoju niektórych miast może powodować, że chaos budowlany i pośpiech projektowy mogą doprowadzić do uszkodzeń struktury i działania miasta. Chęć zmetropolizowania jak największej części miasta pod naciskiem inwestorów i władz miasta sprawi, że stanie się ono przestrzenią, w której człowiek jako mieszkaniec nie będzie się mógł z nią identyfikować a co za tym idzie dbać o nią, szanować i uczyć się z niej. Obecna sytuacja, w której to głównym projektantem są inwestorzy, biura sprzedaży nieruchomości oraz władze miasta sprawiły, że jakość urbanistyki i architektury jest mocno podporządkowana ilości PUM, które daje działka. W niektórych przypadkach jakość urbanistyki to element, który jest pomijany przy tworzeniu zabudowy. Całej tej sytuacji nie pomagają również wycinkowo tworzone miejscowe plany zabudowy. Stąd potrzeba wytworzenia dialogu pomiędzy każdą z tych grup. Próba włączenia społeczeństwa i przyszłych odbiorców danej przestrzeni do wspólnej współpracy i zaangażowania się w jakość tej przestrzeni. Wiedza wynikająca $\mathrm{z}$ użytkowania już istniejących założeń $\mathrm{w}$ mieście może posłużyć jako źródło informacji dla przyszłych planów w mieście. Pozwoli to zrozumieć inwestorom, projektantom jakie są oczekiwania każdej z grup. Pomysł na zbieranie i wymianę takich danych można przekuć w stworzenie budynku - „serwera informacji” na zasadzie podobnej do Gdyńskiego INFOBOX (rys. 1.).

Miejsca w którym rozmawia się o jego rozwoju, dyskutuję się na temat dalszych przestrzeni pod zabudowę lub modernizację. Miasta takie jak Rzeszów, które w szybkim tempie kształtują i zabudowują swoje tereny powinny czerpać opinie i korygować swoje założenia $\mathrm{z}$ już istniejących rozwiązań w mieście. Rzeszów posiada w swoich granicach założenia i rozwiązania funkcjonujące już kilka lat. Pomimo że są to realizacje pochodzące z epoki, kiedy to budynki były podporządkowane prefabrykacji oraz silnym naciskom władzy, można z nich odczytać poprawne i funkcjonujące po dzień dzisiejszy założenia [1-4]. 


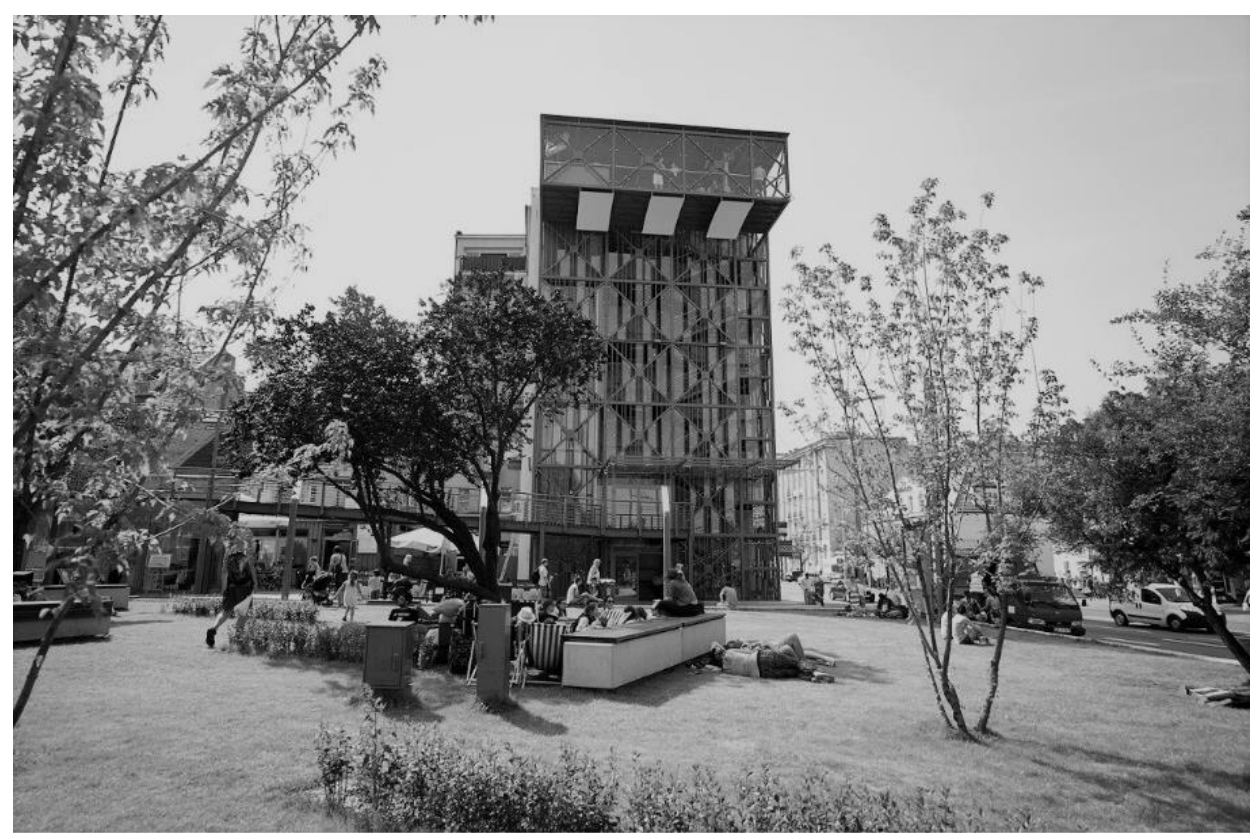

Rys. 1.Budynek Infobox w Gdyni; na podstawie: www.trojmiasto.pl

Fig. 1. Infobox building in Gdynia

\subsection{Osiedle Kmity w Rzeszowie - architekt Zdzisław Kłodkowski}

Zespół 35-pięciu budynków mieszkalnych mieszczący się na 20 hektarach. Dodatkowo otoczony 10 hektarami terenów zielonych. Obecnie zamieszkuje go około 7 tysięcy osób. Jest to przykład osiedla budownictwa spółdzielczości mieszkaniowej. Próbą było zaprojektowanie osiedla działającego jako samowystarczalne, poprzez usytuowanie w nim usług typu - przedszkola, żłobki, służba zdrowia, pawilony handlowe, tak aby osiedle wytwarzało więź społeczną wewnątrz zamieszkującej jej ludności. Większość założeń z projektu została zrealizowana, ale tak nowatorski pomysł jak parking wielopoziomowy, który miał obsługiwać osiedle nie spotkał się z aprobatą i nie został zrealizowany. Pomimo upływu czasu osiedle jest jednym z najbardziej zielonych osiedli w Rzeszowie. Również relacje społeczne po dzień dzisiejszy utrzymują się na wysokim poziome (rys. 2.). 


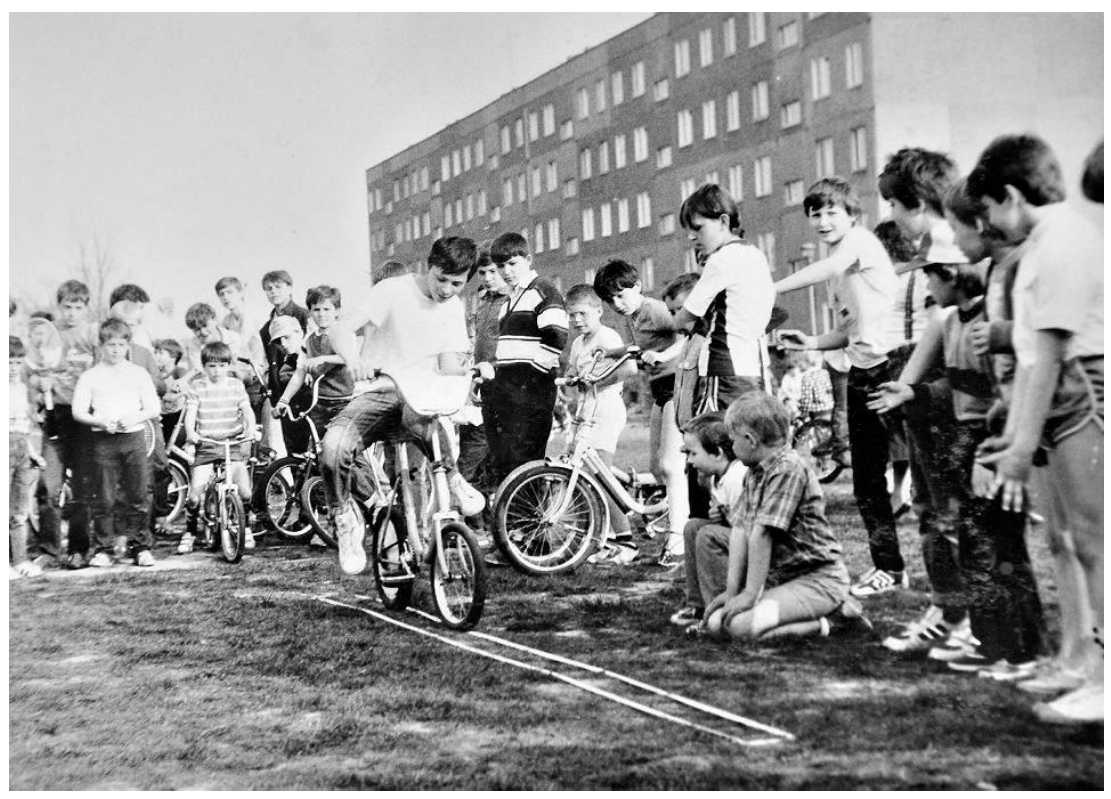

Rys. 2. Zabawy i gry z okazji dni osiedle. Zdjęcia udostępnione przez ODK „Gwarek”

Fig. 2. Inhabitants during days of estate

\subsection{Osiedle przy ulicy gen. J. Dąbrowskiego w Rzeszowie - architekt Józef Polak}

Osiedle Dąbrowskiego jest jednym z najstarszych osiedli w Rzeszowie. Budowę osiedla rozpoczęto przed wybuchem drugiej wojny światowej w 1937 roku. Osiedle miało być zapleczem mieszkaniowym dla rozwijającego się centralnego okręgu przemysłowego. Miały tu powstać mieszkania dla WSK. Budowa odbywała się w ekspresowym tempie bo w zaledwie 5 lat ukończono wszystkie budynki. Architektura osiedla to realizm socjalistyczny, socrealizm, który na tym osiedlu przebija się na elewacjach oraz widoczny jest w budynku domu kultury WSK obecnie Instytut Muzyki UR (rys. 3.). 


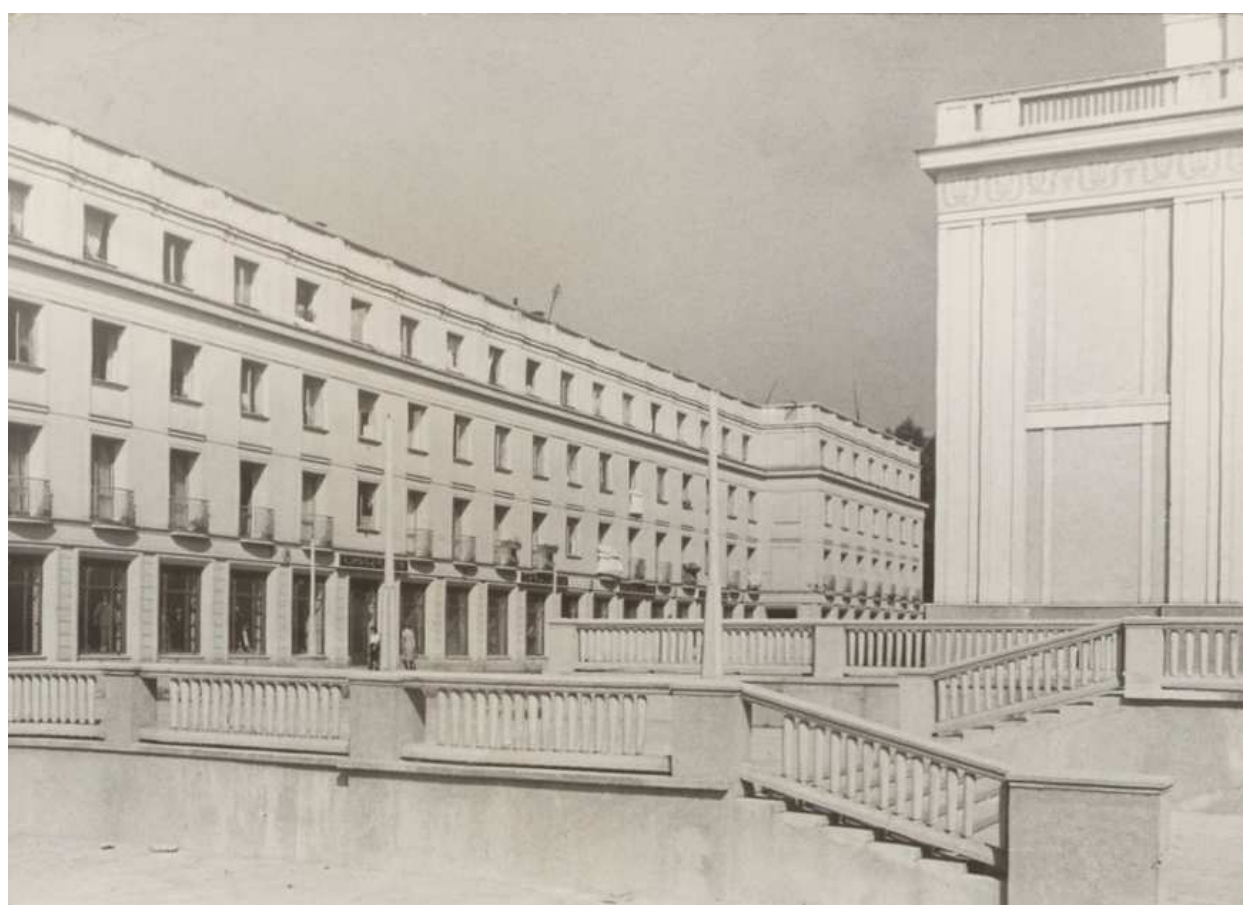

Rys. 3. Blok przy ulicy gen. J. Dąbrowskiego. Fot. G.Russ, z archiwum prywatnego A. Kruka

Fig. 3. Building in Dąbrowskiego street

\subsection{Osiedle przy ulicy Hetmańskiej w Rzeszowie - architekt Zbigniew Tomaszewski}

Osiedle Hetmańska, dawniej osiedle Stalingradu 2, to pierwsze osiedle zaprojektowane przez rzeszowskiego architekta. Zbigniew Tomaszewski przełamał monopol architektów warszawskich na terenach Rzeszowa. Zespół budynków usytuowany prostopadle wzdłuż ulicy Lenartowicza. Kompozycja od strony wschodniej została domknięta budynkami 11 kondygnacyjnymi, które wykonano według indywidualnego projektu. Nazywano je „wieżowce na tle łąk”, prześmiewczo urągając aspiracjom Rzeszowa do budownictwa wysokiego. Od strony zachodniej osiedle zostało domknięte pasażem usługowym od strony ul. Hetmańskiej. W latach 70. architekt Stanisław Majka zaprojektował układ pawilonów usługowych, które dodatkowo spełniły funkcję wyciszająca osiedle i dały oddech od drogi budynkom mieszkalnym (rys. 4.). 


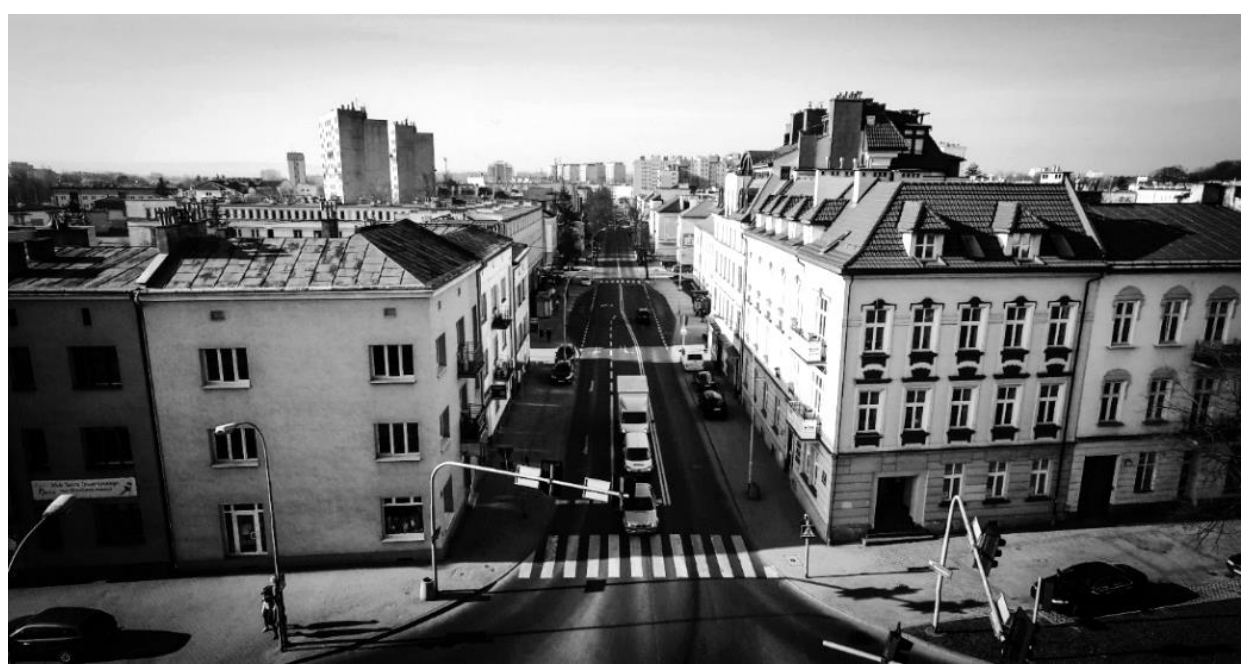

Rys. 4.ul. Hetmańska. W głębi widoczne budynki wysokie przy ul. Lenartowicza. Źródło: rzeszow.naszemiasto.pl

Fig. 4. Hetmańska street. Deep inside buildings next to Lenartowicza street

\subsection{Osiedle Zalesie w Rzeszowie}

„Za lasem” gdyż lokalizacyjnie pola i łąki przewidziane na realizację osiedla znajdowywały się za lasem. W czasie wojny łąki Zalesia były używane jako lotnisko polowe. Ta myśl że można to miejsce wykorzystać aby stworzyć lotnisko została nawet zapisana w powojennym pierwszym planie Rzeszowa $1955 \mathrm{r}$. Miało się tam znajdować lotnisko aeroklubu i ewentualne lotnisko pomocnicze. Niestety zrezygnowano $\mathrm{z}$ tej myśli pozostawiając łąki. Poszukiwania w latach 70. Terenów, na których w sposób zaplanowany będzie można zrealizować osiedla domów jednorodzinnych sprawiły, że łąki Zalesie stały się idealnym miejscem na takie przedsięwzięcie. W pracowni urbanistycznej został opracowany miejscowy plan szczegółowy dużego fragmentu łąk położonych na południe od ulicy Łukasiewicza. Obszar liczący 90 hektarów został przeznaczony pod zabudowę jednorodzinną o określnym charakterze architektonicznym. Do wyboru opracowano różne projekty domów. Plan opracowany został pod kierunkiem architekta Stanisława Wantucha. Zauważył on, że wchodząc zabudową w te tereny niszczy się naturalne siedlisko kwiatów zimowit dlatego nazwał Osiedle Zimowit. Upamiętniając w ten sposób jego występowanie na tych terenach. Osiedle posiada charakterystyczny układ komunikacyjny. Został on opracowany na planie wykonanych przed laty rowów melioracyjnych. Do rowów doprojektowano układ komunikacyjny i wpuszczono je do kanalizacji deszczowej wykorzystując w ten sposób naturalne elementy tych łąk. Osiedle Zimowit bardzo sprawnie zostało zagospodarowane. Projektowane tam budynki miały 
duże wymogi architektoniczne co do jakości architektury. Realizowali tam swoje projekty różni architekci Rzeszowa - Stanisław Kokoszka, Stanisław Wantuch, Wiesław Parkiewicz, Zbigniew Tomaszewski, Czesław Wajdowicz. Było to osiedle prestiżowe, takim się stawało co sprawiło, że wzrosło zainteresowanie i zapotrzebowanie na taki rodzaj zabudowy. Chęć dalszej realizacji sprawiła, że od strony północnej ulicy Łukasiewicza zaczęto kontynuować rozwinięcie osiedla nawiązując się układem komunikacyjnym i charakterem przestrzennym. Projektantem dalszej części osiedla była Stanisława Gubernat. Na początku lat 90 osiedle miało już 120 hektarów powierzchni. Jego prestiż wzrósł jeszcze bardziej w momencie zapotrzebowania budowy kościoła dla Nowego Miasta i Drabinianki. Jednak ówczesne władze komunistyczne nie chciały zgodzić się na budowę kościoła w tym rejonie. Wydano decyzję na budowę kościoła na uboczu Rzeszowa. Stąd decyzja zlokalizowania kościoła właśnie w rejonie nowego osiedla Zimowit. Projekt powstał przy udziale trzech architektów. Kazimierz Ferenc, Józef Trzeciak i Tadeusz Karyś. Obawa ówczesnego proboszcza że tak młody zespół nie będzie mieć siły przebicia sprawiła że projekt zlecono krakowskiemu architektowi Witoldowi Cęckiewiczowi. Kościół ten w 1992 r. został Katedrą dla nowo powstającej diecezji rzeszowskiej.

\subsection{Osiedle Baranówka w Rzeszowie-architekt Krzysztof Degórski}

Plany rozwoju miasta zakładały wzrost liczby mieszkańców, początkowa decyzja rozwoju na wschód pominęła tereny obecnej Baranówki jako miejsce na osiedle mieszkaniowe. Tereny te pozostawały jako miejsce dla gospodarstw jako tereny rolne. Dzielono je na duże obszary rolne po czym, jak się okazało właściciele dzieli je na mniejsze działki i sprzedawali pod zabudowę. Przy ulicy Zwierzynieckiej powstawały więc domki jednorodzinne a w późniejszym czasie pojawiały się pierwsze budynki wielorodzinne przy ulicy Okulickiego zwane później osiedlem 20-lecia. Założenie to składało się wyłącznie z budynków mieszkalnych. Od ulicy Okulickiego były to budynki z usługami w parterze indywidualnie zaprojektowane, pozostała zabudowa to budynki o dokumentacji importowanej - oszczędnościowej. Dopiero na przełomie lat 60. i 70. podjęto decyzje, aby opracować plan szczegółowy pozostałej dzielnicy mieszkaniowej która miała posiadać przedszkola, żłobki oraz pawilony usługowe. W 1972 roku był już gotowy projekt nowego osiedla Baranówka (rys. 5.). 


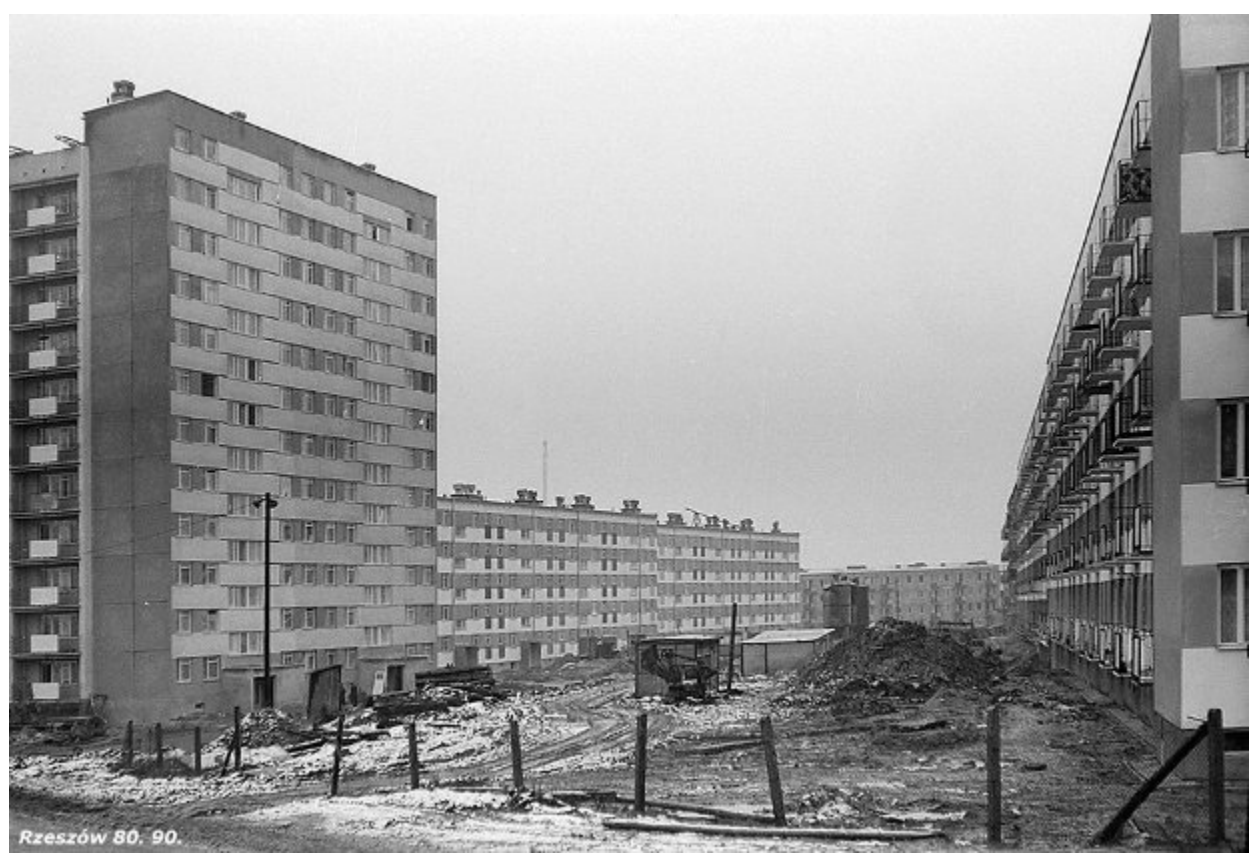

Rys. 5.Osiedle Baranówka w trakcie ralizacji; na podstawie: projekty.wimbp.rzeszow.p

Fig. 5. Baranówka estate during the constraction.

Osiedle imienia gen. Władysława Andersa jest przykładem osiedla całkowicie podporządkowanego prefabrykacji, gdzie kształt i wielkość budynków wynikały z dostępnych materiałów. Do tego stopnia, że plan zakładał tam budowę tylko budynków pięciokondygnacyjnych, gdyż budynki średnio wysokie miały się pojawić w dzielnicy Nowe Miasto. Władysław Hennig jako szef pracowni planowania miejskiej pracowni urbanistycznej nie zgodził się na takie zachowanie i wymusił powstanie kilku budynków średnio wysokich, które akcentowały ważniejsze miejsca na osiedlu. Architekt Krzysztof Degórski wspomina że każdy projekt realizowany $\mathrm{w}$ ramach zjednoczenia musiał być uzgadniany z tym przedsiębiorstwem w najdrobniejszych szczegółach - forma, materiał konstrukcyjny, wykończenia podłóg i ścian. Powstałe długie wnętrza pomiędzy prefabrykowanymi budynkami miała wypełnić mała architektura. W tamtych czasach nikt nie chciał zgodzić się na dodatkowe prace murarskie, które były pracochłonne i wymagały dodatkowych materiałów. Architekci postanowili wykorzystać „łupiny nadkanałowe”, które były wykorzystywana do budowy kanałów podziemnych instalacyjnych. Gotowe elementy można było zestawiać w taki sposób, aby uzyskać formy małej architektury wnętrz osiedli np. ławki kwietniki. Wiele tych elementów zostało ustawionych w trakcie budowy. Ale niestety, kiedy ekipa porządkowała teren, potraktowała to jako pozostałości po budowie i rozebrała tzw. ,małą architekturę". 


\subsection{Dzielnica Nowe Miasto w Rzeszowie}

W 1959 r przeprowadzono ogólnopolski konkurs urbanistycznoarchitektoniczny na zabudowę terenu dla realizacji dzielnicy Nowe Miasto. Spośród 29 prac zostały wyróżnione trzy zespoły reprezentujące różne miasta - Katowice, Rzeszów, Warszawa. Plany realizacji jakichkolwiek założeń musiały zostać odłożone w czasie, gdyż brakowało pieniędzy na uzbrojenie terenu pod inwestycję. W związku z tym rozwój i planowanie miasta poszedł w kierunku Baranówki, osiedla 1000-lecia i osiedla 20-lecia. Nowe miasto musiało ustawić się w kolejce do realizacji. W latach 60 tych rozwiązania zawarte w tych projektach posłużyły do opracowania planu szczegółowego zagospodarowania 40 hektarów przyszłej dzielnicy Nowe Miasto. Ogłoszono drugi uproszczony konkurs urbanistyczno-architektoniczny. Zaproszono 4 zespoły autorskie - dwa biura z Rzeszowa jedno z Katowic i jak się później okazało zwycięskie biuro z Warszawy. Duży wpływ na wybór zwycięskiego projektu miały władze kombinatu budowlanego. „Mieszkaniówka” która w tych czasach preferowała budownictwo powtarzalne, proste i realizowane na dużych przestrzeniach zdecydowanie popierała rozwiązania zawarte w koncepcji zespołu z Warszawy. Głos w sprawie wyboru koncepcji miała także dyrekcja centralnego związku spółdzielczości i budownictwa mieszkaniowego w Warszawie. Rozstrzygniecie konkursu odbyło się $\mathrm{w}$ formie publicznej prezentacji prac. Zaproszeni koreferenci nie ocenili zbyt wysoko pracy z Warszawy. Decydującym aspektem była prezentacja koncepcji, która została przeprowadzona na wysokim poziomie. I to sprawiło, że pomysł architektów z Warszawy został pracą zwycięską. Konkurs rozstrzygnięto 1970 r. Architekci Wiesław Rzepka, Zbigniew Pawelski, Andrzej Dzierżawski zaproponowali koncepcje osiedla najłatwiejszego w realizacji. Pomysł zakładał wybudowanie powtarzalnych 11 kondygnacyjnych bloków w technologii elementów wielkiej płyty. Metoda szybka i tania. Realizację osiedla rozpoczęto w 1973 roku. Z czasem projekt koncepcyjny został uproszczony do jednakowych budynków usytuowanych w linii prostej północ-południe. Tak aby ułatwić przewietrzanie oraz odpowiednie naświetlenie mieszkań. Autorzy projektu po opracowaniu jego głównych założeń nie brali udziału w dalszych szczegółowych pracach, co spowodowało dalsze upraszczanie początkowej koncepcji. Uproszczeniu uległ nawet projekt funkcjonalny obiektu. Początkowo w projekcie partery miały posiadać zróżnicowane funkcje, miały się tam znajdować mieszkania dla osób starszych i niepełnosprawnych, lokale do użytku wspólnego mieszkańców, mini przedszkole. Zaproponowano nawet wykonanie zielonych ogrodów na dachu, które niestety nie zostały wykonane. Wszystkie te założenia miały być kontynuacją założeń karty ateńskiej, stworzenie przyjaznej przestrzeni do życia. Stąd też duże odległości między budynkami, które jak się okazało wynikały również z technologii budowy. Ustawione pomiędzy budynkami żurawie budowlane miały łatwość w obsługiwaniu dwóch jednostek budowlanych z jednego miejsca. W obliczu tak monotonnej zabudowy podjęto próbę zróżnicowania 
zabudowy na Nowym Mieście. Zaczęto doprojektowywać nowe budynki. Pojawiły się domy szeregowe od strony ulicy Podwisłocza oraz dom seniora i pawilony usługowe. Obecnie osiedle takie jak Nowe Miasto próbuje się cywilizować w różne sposoby. Można zauważyć próby „ożywienia” prefabrykacji nadając budynkom nowy wygląd poprzez jaskrawe kolory. Modna w ostatnich czasach „pasteloza” (rys. 6.). Na zachodzie odchodzi się do takich dzielnic w dwojaki sposób. Próbuje się ją ratować różnymi dobudówkami i nadbudowami lub traktuje się ją dynamitem.

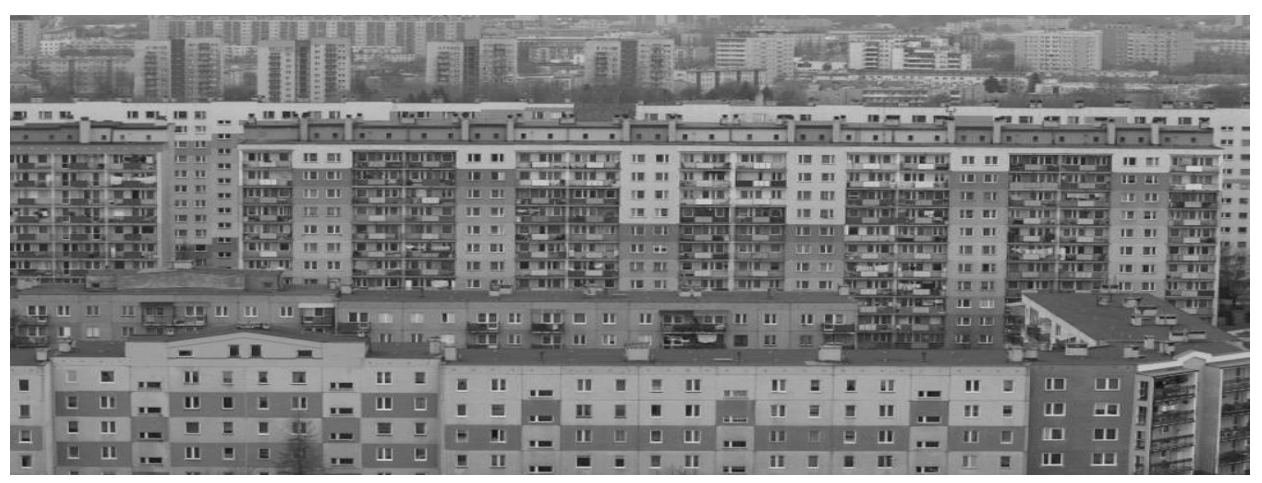

Rys. 6.Osiedle Nowe Miasto; na podstawie: nowiny24.pl

Fig. 6. District New Town in Rzeszów

„Kreatywność kocha ograniczenia, bo dzięki nim powstaje najwięcej innowacyjnych pomysłów". Pojawia się myśl czy w obecnych czasach im bardziej skomplikowany problem mamy do rozwiązania, tym większa powinna być potrzeba jego uproszczenia. Czy właśnie nie staroświecki zdrowy rozsądek i chęć zrównoważenia wszystkich elementów nie powinny być próbą przełożenia tego w formę. Nie chodzi tu o pieniądze lecz o koordynację. Kluczem do sukcesu jest szacunek dla tradycji połączony z eksperymentowaniem z nowymi technikami. Tworzenie Takich projektów, które będą wywierać wpływ na okoliczną przestrzeń i lokalne społeczeństwo Nieustanny dialog z naturą i tradycją sprawi że społeczeństwo będzie oczekiwało dobrej jakości. Architektura powinna służyć ludziom, nie za pomocą „budynków ikon” lecz budynków, które pobudzają i zachęcają do interakcji, zaangażowania się w dalszy rozwój przestrzeni, w której się znajdują. W tym kontekście architekci rzeczywiście mają do odegrania ważną rolę w kształtowaniu społeczeństwa i interakcji międzyludzkich, ale to nie jest tylko ich zadanie. Za projektem musi iść dobre planowanie przestrzenne, rozsądna polityka miejska i mądre władze. W działalności nic się nie marnuje, idee $\mathrm{z}$ każdego niezrealizowanego projektu zostają można z nich korzystać przy tworzeniu kolejnych. Właśnie takie miejsce jak Infobox w Gdyni daje takie możliwości, nie tylko wymiany opinii i poglądów mieszkań- 
ców. Stworzono tam makietę całego miasta do wglądu dla każdego. Mieszkańcy mogą w dowolny sposób umieszczać elementy zabudowy w celu sprawdzenia jak dana przestrzeń mogłaby wyglądać. Jest to również miejsce prac planistów, którzy mogą dokonać sprawdzenia swoich zapisów przed ich uchwaleniem i wprowadzeniem w życie (rys. 7.).

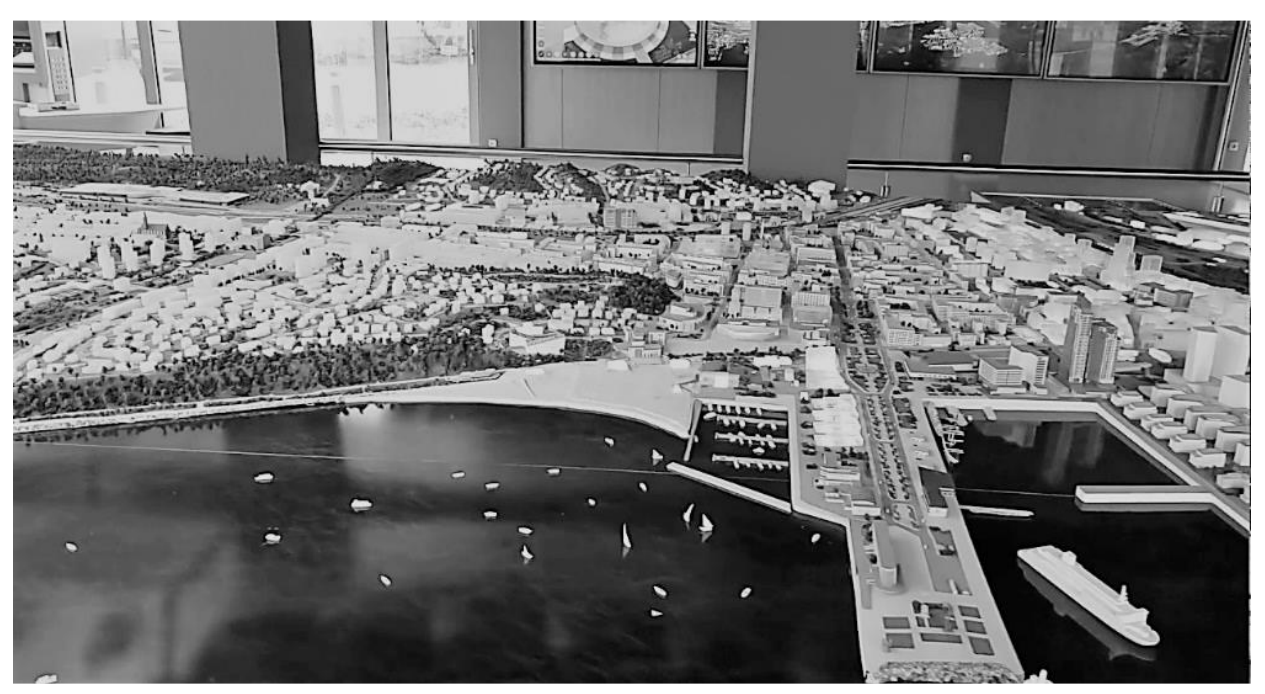

Rys. 7 Makieta miasta Gdynia w budynku Infobox, na podstawie: www.trojmiasto.pl

Fig. 7. Model made for Gdynia inside Infobox building

Ogłaszanie konkursów oraz ich rozstrzyganie z debatą po i przed konkursową w takim miejscu miało by też duży udział w kreowaniu świadomości mieszkańców. Często praca architekta w konkursach jest ograniczana sztywnymi zapisami, które nie pozwalają projektantom na pełną kreatywność. Rodzi to późniejsze zarzuty do prac związane z brakiem stosowania się do zasad konkursu. A przecież w pracy architekta nie o to chodzi. Projektant musi przełamywać granice, testować nowe materiały i technologie oraz kreować nowe zasady. Proces tworzenia nowych budynków składa się z wielu faz i elementów co sprawia, że zaangażowanych w niego jest wielu ludzi. Architekt w dzisiejszych czasach to nie tylko solidny inżynier, to ktoś więcej. To osoba, która łączy ludzi (z wiedzą i umiejętnościami) z wielu dziedzin techniki. Koordynatorem, który potrafi wykorzystać i docenić potencjał w już istniejących elementach miasta, tak aby wnieść do niej jak najwięcej poprawnych rozwiązań. Dlatego tak ważnym jest analizowanie kontekstu we wszystkich wymiarach: historycznym, kulturowym i materialnym. Należy powstrzymać dewastację przestrzeni publicznej słabymi planami miejscowymi, które są realizowane wyrywkowo i wycinkowo na potrzeby szybkiego zabudowania danej przestrzeni. Słaby plan miejscowy daje pole do tego, żeby daną przestrzeń popsuć. „Odpowiedzialność społeczna, śro- 
dowiskowa i ekonomiczna pojawia się wtedy, gdy budynki są kochane przez ludzi, którzy je zamieszkują". W Polsce nadal brakuje niektórych regulacji i wiele rzeczy puszczane jest na żywioł. Wyzwaniem dla polskich miast jest teraz budowanie domów mieszkalnych w centrum miasta oraz budowa sprawnej komunikacji. Tak aby więcej ludzi mieszkało w mieście a nie tylko na obrzeżach. Budowanie mieszkań $w$ centrum pozwala też na zmniejszenie ruchu i przeciwdziała korkom w mieście. Architekci, deweloperzy i urzędnicy powinni współpracować w tych kwestiach. To się wszystkim opłaca.

\title{
Literatura
}

[1] Franciszek K.: Tamten Rzeszów, Krajowa Agencja Wydawnicza Rzeszów 1985.

[2] Jadam H., Malikowski M.: Rzeszowianie o sobie i swoim mieście, Towarzystwo naukowe w Rzeszowie

[3] Babelski B.: Rzeszowskie lekcje Architektury.

[4] Fragmenty z wywiadu z A. Levete, Futu.pl

\section{DESIGN PARTICIPATION IN URBAN PLANNING AS SOURCE OF EXCHANGE KNOWLEDGE AND EXPERIENCE}

\begin{abstract}
S u m m a r y
In times when developers are creating architecture there is a need of dialog between investors and inhabitants. Inhabitants' experience and opinions (relations that are made when you use the town space) of existing estates should be included and considered in creating new developing urban plans. Development of the city should be openly discussed. Plans and models could be not sufficient in this case. Creating a special, dedicated place for such discussions, interchange of opinions and ideas might be a solution. Place where inhabitants have a real influence on changes in their city. Such a place, called INFOBOX, exists in Gdynia. Inhabitants together with architects, investors and city councils use it as a platform of exchanging, sharing their visions. This place encourages all inhabitants to participation and involvement in the city development. With this approach process of changing our mindsets could be started. Nevertheless it will take years. City is a constantly changing structure but it doesn't mean that we cannot take solutions and ideas from the past. Heritage of previous generations can and should be a direction for further changes. We should take a closer look to compositions, forms and locations of existing estates. In this context few areas in Rzeszow (e.g. Baranowka, Nowe Miasto, Zalesie) were considered.
\end{abstract}

Keywords: interaction, urban planning, participation

Przestano do redakcji:09.06.2017 $r$.

Przyjęto do druku: 01.09.2017 r. 